\title{
Migration, Farmer-Herder Conflict and the Challenges of Peacebuilding in the Agogo Traditional Area, Ghana
}

\author{
Mary Boatemaa Setrana ${ }^{1 *}$ \\ Justice Richard Kwabena Owusu Kyei²
}

\begin{abstract}
:
Recently, communities in Agogo Traditional Area (ATA) have witnessed an increasing spate of violence leading to loss of lives, loss of livelihoods, insecurity and severe injury among others. This article explores the "local" in peacebuilding by addressing the following research questions: first, how do Agogo indigenes in the diaspora contribute to peacebuilding in Agogo Traditional Area? Second, in which ways do the engagement of Fulani herders and indigenous farmers influence the process of peacebuilding in Agogo Traditional Area? The article employed in-depth interviews, participant observation, key informant interviews and focus group discussions in the data collection process. From an interdisciplinary perspective, the research has introduced the activities of transnational migrants into the discourse of peacebuilding as it positions Ghanaians in the diaspora as local actors engaged in the farmerherder conflict in ATA. This study has shown that in the case of ATA, despite the potential benefits of the local peacebuilding including the contribution of the diaspora, it is bedeviled with challenges such as mistrust and inadequate resources. The article recommends that local peacebuilding be detached from adjudication in the court of law because the local actors perceive the court as external and ambivalent to the cultural context of local conflicts.
\end{abstract}

Keywords: local peacebuilding, farmer-herder conflict, diaspora, Agogo Traditional Area, Fulani

\footnotetext{
${ }^{1 *}$ Centre for Migration Studies, University of Ghana ${ }^{2}$ Department of Sociology and Social Work, Kwame Nkrumah University of Science and Technology Corresponding Author: mbsetrana@ug.edu.gh
}

Ghana Journal of Geography Vol. 13 (2), 2021 pages 340- 357

https://dx.doi.org/10.4314/gig.v13i2.13 
Migration, Farmer-Herder Conflict and the Challenges of Peacebuilding in the Agogo Traditional Area, Ghana

\section{Introduction}

The Conflict Transformation Approach (Lederach, 1997) in the farmer-herder conflict in Agogo Traditional Area (ATA) has paved the way for the involvement of local actors. In Ghana and other parts of Africa, authority, status and social capital of traditional and religious leaders make them very powerful agents of peace in their communities (Tonah, 2002; Lund, 2009; Bukari et al., 2018). Local actors prevent violent conflict and promote peace when micro-level approaches are contextually engaged and supported by the state and the affected communities (Yakohene, 2018).

The conflict between pastoralist and sedentary communities exist in many states across subSaharan Africa. Clashes over land tenure are common (Bukari et al., 2018). Some studies include the works of Kagwanja (2003) and Martin (2012) on the Tana River in Kenya, Benjaminsen and Ba's (2019) study on farmer-herder conflict escalations in Mali. Olaniyan et al. (2015), Bukari et al. (2018) and Paalo (2020) have worked on the causes of the conflict and co-existence between Fulani herders and farmers in Ghana. However, what is not clear in these previous scholarly works, which this article seeks to address, are the contributions of Agogo indigenes in the diaspora to the peacebuilding in the farmer-herder conflict in Agogo as well as the lived experiences of the farmers and herders in promoting peace. These conflicts continue to affect many livelihoods, and therefore, a better understanding of how the local actors promote peace is very important. The research is timely because of the interdisciplinary approach that it adopts in the introduction of transnational migration perspective into peacebuilding studies, which previous studies have not problematized (see: Tonah, 2002; Yakohene, 2018).

This article aims at contributing to the existing knowledge on local peacebuilding studies by addressing the following research questions; first, in which ways do the engagement of Fulani 
pastoralists and Agogo farmers influence the process of peacebuilding in Agogo Traditional Area? Secondly, how do Agogo indigenes in the diaspora contribute to peacebuilding in Agogo Traditional Area? The article relies heavily on the conflict transformation local peacebuilding by Lederach (1997) as it seeks to unravel the role of the diaspora and others actors in negotiation, sensitization, mediation, informal conversation as well as dialogues in an attempt to build peace in ATA. The article is divided into the following sections: first we conceptualize local peacebuilding theory and the actors involved in the process. We then present the study area and methods employed in the study which is followed by the section on findings and discussions and finally the conclusions.

\section{Literature Review: Conceptualizing Local Peacebuilding Theory and Actors}

The concept of peacebuilding was first developed in 1975 by Galtung, but it gained prominence only in the early 1990s. Galtung (1975) established the three distinctive meanings that exist among the approaches of peace, namely, peacemaking, peacekeeping and peacebuilding. Peacemaking is considered as an attempt to stop an ongoing conflict through negotiations, enquiry, sanctions and blockading while peacekeeping deals with how to prevent the resumption of fighting following a conflict. Peacebuilding according to Galtung (1975) is a structural mechanism involving multiplicity of actors at the local, national and international levels to address the immediate impacts and root causes of conflict before, during and after violent conflict has occurred. The aim of peacebuilding processes is to manage, mitigate, resolve and transform through official diplomacy, civil society, informal dialogues, negotiations and mediations. Lederach (1997) understands peacebuilding as a comprehensive concept that encompasses, generates, and sustains the full array of processes, approaches, and stages needed to transform conflict toward more sustainable and peaceful relationships. The introduction of the concept of peacebuilding has shifted the interest of peace research from 
Migration, Farmer-Herder Conflict and the Challenges of Peacebuilding in the Agogo Traditional Area, Ghana

international actors to local actors (Pattenholz, 2014) as it positions local actors as the driving force in peacebuilding.

This article draws on Lederach's (1997) theory of Conflict Transformation (CT) peacebuilding as it focuses on locals as the owners of the peacebuilding process. Lederach argues that peacebuilding is a long-term process of systemic transformation in the personal, structural, relational and cultural aspects of conflict to peace. CT peacebuilding theory places emphasis on reconciliation and the essence of rebuilding broken relationships (Paffenholz, 2014). The theory was developed out of the failed externally driven peacebuilding processes in Angola, Rwanda and Southern Somalia while concurrently locally owned, bottom-up approaches led to fruitful peacebuilding in Northern Somaliland. The emphasis of Lederach on locally owned peacebuilding is the backbone of the theory as it departs from previous approaches in peacebuilding and develops a new paradigm in peacebuilding studies (Fetherston, 2000; Pattenholz, 2014; Reimann, 2004). Interestingly, Lederach (1997) draws the peacebuilding resources in society through the 'middle-out' approach in which a conflict society is divided into three categories of actors in pyramidal form namely: top leadership, middle level leadership and grassroots. Lederach (1997) stressed the potential of the middle level leadership in establishing and sustaining peacebuilding processes over a long period.

From an interdisciplinary approach, this article brings into the discussion of peacebuilding research the migration perspective as it positions transnational migrants as local actors who contribute to peacebuilding in their hometowns (Mahmood, 2006). Studies on the transnational activities of Ghanaian immigrants have stressed on the infrastructural developments in their hometowns, contributions to the sustenance of families, political participation, transnational religious practices and even care of left behind children and spouses (see Setrana \& Kyei, 2015). Studies have discussed the activities of civil societies in ethnic conflict resolution and peacebuilding in the northern parts of Ghana (Kaye \& Beland, 2009; Kaye, 2011). There is 
lacuna however, in the literature on the contribution of Ghanaian diaspora in peacebuilding in their hometowns and this paper seeks to fill the research gap. We argue that Ghanaians abroad are not external actors; rather they are local actors operating within the transnational space that is living 'here' and 'there'. Diaspora associations have shared sense of consciousness, values and norms with the place of origin (Mangala, 2017). We situate Ghanaian migrants as middle level leadership in the Lederach's pyramid due to the influence that they have back home.

The ownership of peacebuilding by local actors facilitates the adoption of bottom-up approach (Ginty, 2014) involving routinized practices and norms deployed by individuals and groups in deeply divided societies to avoid and minimize conflict. Peacebuilding among farmers and herders in the Agogo traditional area is conceptualized as the activities and programs generated by the diaspora, the traditional council, as well as the lived experiences of the herders and farmers in transforming the conflict. We conceptualize the activities outlined under the local turn of peacebuilding as community associations; funds mobilization, negotiations among affected actors, informal dialogues, peace sensitization programs. The sensitization programs are done through radio, television and community durbars.

\section{Study Area and Methods}

The study was conducted in six communities, located in the Agogo Traditional Area (ATA), namely Agogo, Onyimso, Pataban, Nyamebekyere, Ananekrom and Nyinatokrom all in the forest transitional zone of Ghana. The area was selected because of the major incidence of conflict, which resulted in about 12 Deaths, 16 injuries, and 300 crops damaged between 2009 and 2013 (Bukari et al., 2018). The indigeneity and livelihoods of farmer-herder conflicts is becoming a common feature of this community especially between the months of December and March when the weather is dry. The Twi-speaking Akans are the dominant ethnic group in the area but there are migrant settlers mostly from the Northern and Volta regions as well as 
Migration, Farmer-Herder Conflict and the Challenges of Peacebuilding in the Agogo Traditional Area, Ghana

Fulani herders. The indigenes are mostly Christians while the Fulani herders are Muslims. It is the most populated district with about 69,186 people as of 2010 (Ghana Statistical Service, 2013). The rural dwellers constitute $53.5 \%$ while the urban population is approximately $46.5 \%$. The main occupation of the people of the Agogo Traditional Area is farming, which employs about $72.7 \%$ of the labour force.

The empirical evidence is based on a qualitative study of the conflict transformation of local peacebuilding in the six communities. The study was conducted from July to December 2017. Snowballing sampling technique was employed in the recruitment of Fulani herders while convenience-sampling technique was used to recruit the farmers and traders. Purposively, ten key informants who occupied leadership positions among the diverse actors were recruited. Indepth interviews were conducted with thirty-five (35) respondents and the breakdown was as follows: ten Fulani herders and five wives of Fulani herders, ten male farmers and ten female farmers. The ten key informant interviews included were carried out with heads of cattle owners' association, traditional council, youth leaders, hometown association and religious leaders. Participant observation was also employed as a means of data collection. Three different focus group discussions (FDGs) were held with nine respondents in each group. One FDG was held with female farmers; another with male farmers; and the last FDG was held with Fulani herders. The biases associated with snowballing were minimized by identifying different contact persons in the various communities who assisted in the recruitment of Fulani herders.

Permission was obtained from traditional leaders before entering the community and from individual participants before interviewing them. Pseudonyms were used to protect the identity of the respondents. The interviews were mostly conducted in Twi (this is the local language) and translated into English. The interviews were audio-recorded and transcribed verbatim. Line by line, the data were manually categorized into analytic units under descriptive words or 
category names. The information was organized into themes and subthemes (Rossman \& Rallis 1998:171); some of the major themes included, Agogo Worldwide Association in peacebuilding; lived experiences of farmers and herders and challenges of peacebuilding.

\section{Findings and Discussions: Local Peacebuilding Activities in ATA}

This section discusses the role of the local peacebuilding actors in building peace between the farmers and the herders in Agogo traditional area. The bottom-up activities undertaken by these actors in an attempt to resolve the conflict are peace sensitization programs, mediation, negotiations, fund raising and dialogue. These activities are achieved so far through the norms of reciprocity, mutual trust and shared values. Despite the positive contribution of the local peacebuilding actors, they also face challenges, which heightens the tension between the farmers and herder instead of resolving the conflict.

\section{Agogo Worldwide Association in Peacebuilding}

From the field observation, the agency of the native farmers is reflected in their initiative to seek non-violent and legal redress in resolving the conflict. Some literature (example Collier, 2000; Faist, 2005; Mahmood, 2006) have highlighted the efforts of migrant associations in peacebuilding in the home country. In the case of Agogo, the Diaspora hometown association that assisted in negotiation and dialogues with the aim of resolving the conflict was known as Agogo Worldwide Association (AWA). AWA was formed in 2003 with the aim of mobilizing diaspora resources and minds together in support of Agogo Township. AWA has about 500 members based mainly in the USA, and some in other parts of Canada and Europe. Members among other things also share ideas on how to manage farmer-herder conflicts. AWA has five officers who manage affairs: the president, vice, the general secretary, the public relations officer and the financial person. AWA contributed to managing the farmer-herder conflict by raising funds from its members abroad to sponsor sensitization programs that educated the 
Migration, Farmer-Herder Conflict and the Challenges of Peacebuilding in the Agogo Traditional Area, Ghana

farmers on how to manage themselves in their farms, when they are attacked by herder animals. Other associations, which were involved in building peace in ATA included the Agogo Hometown Associations and the Fulani Association of Ghana.

Some of the activities initiated by the associations were demonstrations and 'protests' against the negative consequences of the conflict on the livelihood of the community since farming is the main occupation of the people of Agogo (interview with a representative of the association, 2017). These protests took place to create an awareness of the challenges posed by the conflict and calling for attention to resolve the conflict. As part of the associations' aim to resolve the conflict, the Agogo associations on behalf of the farmers, wrote series of letters to the executive arm of government to register their displeasure about the happenings in the traditional area. In these letters, they demanded for the removal of the Fulani herders and their animals from Agogo traditional area. A section of the sample letters reads:

the entire citizens of Agogo, home and abroad and the surrounding communities hereby, state categorically that we will never allow [the chief] to relocate Fulani herders and their cattle to any part of Agogo stool lands (extracted from the Traditional Council Archives, interviews with the Traditional Council Chief of Staff, August, 2017).

Such sample letters were issued intermittently to demonstrate their interest and commitment to the ongoing peace processes with the aim of managing the conflict. Among the reasons for the associations' commitment the increasing deaths, injuries and destruction of properties ${ }^{1}$. Key informant interviews revealed that the diaspora owned farms and therefore, were directly affected by the on-going farmer-herder conflict in the Agogo Township. The phenomena also demonstrate how local actors are not only those who are physically present in the conflict location but involve also citizens who live outside the home territory, which are made possible to advancement of communication technologies. One of the members of the association shared

\footnotetext{
${ }^{1}$ According to Bukari et al. (p. 85), there were 12 deaths, 16 injuries (gun shots/cutlass wounds) and 300 crop damage
} 
the concerns of the diaspora association, which indicates that they were internal and not external actors seeking the peace of their community and families:

I had invested in huge acres of land; my family here in Agogo takes care of the farm. The proceeds are used to cater for my wife, children and other siblings while I also receive my share for my own personal spending. In fact, this conflict is not only for those who are back home but for all of us that is why many of us have returned to Ghana to join the demonstrations, protest and peace talk. Oh! Our businesses are here (a transnational actor, and farmer, September 2017).

Although the literature criticizes the diaspora as external actors who may negatively influence peacebuilding because they do not have any direct impact of the conflict (Mahmood, 2005), in the case of the ATA, the story is different. The article argues that the Agogo Diaspora Association is seen as part of the local actors because they are operating and living 'here' and 'there' in the transnational space. They contribute financially through remittances to the daily administration of the peacebuilding agenda. Some of their remittances were used to fund radio and television programs on peace education and co-existence. Moreover, the data show direct investment in farming by some members of AWA.

Another strategy, which was undertaken by AWA to create awareness and restore calmness in Agogo was through education on peacebuilding. The education programmes were carried out on local and popular radio and television stations and well as moving from one community to the other. The farmers through the AWA education program were advised to report any form of farm destruction to the community leaders instead defending themselves from the herders and their animals, which could lead to further disaster. These activities yielded positive results as it minimized the confrontations between farmers and herders.

In addition, instead of using violent means to end the conflict, AWA and the other Agogo Associations, resorted to the use of the court system, which was to prevent the farmers and herders from physically abusing each other; and rather allow the court to adjudicate the case between the two parties. The assumption by the diaspora was that, once the court was involved, 
Migration, Farmer-Herder Conflict and the Challenges of Peacebuilding in the Agogo Traditional Area, Ghana

both parties would have a chance to tell their side of the stories for the court to resolve the conflict. Members of AWA also provided expert advice and professional support to the legal team of the farmers and citizens of the traditional area during the court proceedings. The court also brought calmness to Agogo since the herders and their animals were asked to evacuate the traditional area. The leader of AWA narrated the reasons for the court action as well as the verdict of the court, which brought calmness to the Agogo traditional area.

We filed the case in court, because only the court's ruling could overrule the indenture. On January 20, 2012, the high court issued a mandatory injunction and directed the Ashanti Regional Security Council and Regional Coordinating Council "to take immediate, decisive, efficacious and efficient action to flush out all the cattle from" Agogo Traditional Areal. The final verdict from the court case was that, the Fulani herders had breached contract and were therefore banned from ever stepping foot on the land that belonged to the people of Agogo (leader of the AWA, 2017)

One of the chiefs of the Fulani also shared their experience during the court processes. He said:

Yea, we gave our herders technical support, advised them and also sent some people to be part of the legal team in the court of law. Nevertheless, with the court's ruling, it looks like it is one-sided. The court could not provide a cause and effect explanation; neither did they justify the judgment. Not just concentrating on the fact that the farmers are losing, the farmers are killed, and the farmers are victimized-which is true- but what about the other side? The herders also have lost properties. This case needs to be revisited in a proper way. Our position as an association is to forget about the court ruling and allow the two sides sit together and say that let us come with this solution to resolve the issue once and for all (Fulani Chief, interview, Agogo, August 26, 2017).

Although the court proceedings restored calm, the chiefs indicate that they were not in agreement of the court ruling. Hence, the decision of the court led to antagonism and hatred instead of transforming the conflict and changing the attitude of farmers and herders for coexistence. Eventually, both parties had to come to the negotiation table through dialogue (fieldnotes, 2017).

\section{Lived experiences of the herders and the farmers in peacebuilding}

Another preferred peacebuilding approach by the herders was dialogue. Both farmers and herders preferred discussing the extent of damage with the farmer and compensating the latter 
in a peaceful environment. This is because the compensation needed a process of negotiation, which then provided a platform for both parties to discuss and accept each other's friendship as co-tenants of the same community. The exercise entrusts power in the hands of community members to manage common resources, settle disputes, enforce and impose sanctions. In view of this, they are often respected, and their decisions are perceived as binding due to the fear that the one who acts in breach of the oath will be accursed. One of the local peacebuilding measures involved the traditional authorities such as the chiefs and elders of the community. In cases where the two parties could not agree on the extent of damage and its compensation, the case was reported to the traditional authorities. The traditional authorities assessed the extent of damage and asked the cattle owner to pay for it. The farmers were compelled to report issues to the traditional authorities when the herder and the owner refused to compensate what the farmer was demanding as compensation. Once the case was reported to the chief, the herder was obliged to pay whatever amount because they were aware, that the farmer who happened to be an indigene had a possessory title and again, the chief was the person who leased the land to the Fulani herder. The Fulani herder was quick to act at this stage because he knew the chief could expel the entire Fulani group from the community. This approach was conducted in a peaceful manner and both the farmers and the herders were in favour of it.

Fulani herders mobilized themselves to join in the peace negotiations with the indigenous farmers. One of the chiefs from the Fulani herders narrates some of the peacebuilding messages to the Fulani herders:

If you the herder disagree with the farmer, then you are not looking for peace. To make peace with a farmer, the herder has to accept the complaints made by the herder and calm the farmer down, even if the farmer does not have a positive case, try to make peace. Remember, a farm will never move but the animals, they are moving in different directions, day in and day out, so if there is a problem, you the herder has to sit down, settle it and then move on. If a farmer complains, even if you the herder has a good case, you still need to calm the farmer down because the farm never moves, it cannot attack an animal, it is always permanent (Chief of the Fulani Herders Association, July 27 2017). 
Migration, Farmer-Herder Conflict and the Challenges of Peacebuilding in the Agogo Traditional Area, Ghana

From the above quote, it is obvious that both farmers and herders have different modes of livelihoods; the herders are mobile because they need to search for pasture for their cattle while the farmers are immobile. With this kind of understanding, as noted by the Fulani chief, it should be possible for both farmers and herders to agree on how to resolve the conflict.

On the side of both the farmers and herders, they expressed the disinterest of the state apparatus to support them to resolve the Agogo conflict. In two separate FDGs, both farmers and herders said, the politicians do not want to involve themselves in the situation. Every government that comes to power tries to resolve the problem but the situation has not improved (ATA interview October 3, 2017). However, they both also agree that perhaps there could be compromises between the farmers and the herders. Some of the farmers argued that, if they have 100 acres of farm, which is constantly destroyed by cattle, then perhaps a more durable solution could be giving about 20 acres out to the herders to use for the ranching so that they don't continue destroying their farms. (Interview on October 19, 2019). Similarly, the herders also had responded to adopt the habit of selling some of their cattle in order to acquire at least fifty (50) acres of land for the implementation of the ranching system, once the farmers agreed to give those portions of their land to them.

\section{Challenges of local peacebuilding in Agogo traditional area}

Despite the positive contribution of the local actors to local peacebuilding, there are challenges in the process of transforming the farmer-herder conflict in Agogo. Among them are the heightened tension because of the use of the court and the police in resolving the local conflict, the mistrust of farmers and herders in the powers of the traditional council and the unwillingness of the state in resolving the conflict in Agogo.

The Peacebuilding theory proposes dialogue, negotiation and mediation, but the police service and the court are perceived as external arbiters who do not understand the cultural 
underpinnings of the conflict. A judgement for or against any actor creates superficial calm rather than long lasting peace as proposed by CT peacebuilding theory. The theory promotes negotiation, informal conversation that is contrary to the police approach and/or the court rules and military interventions.

The fieldwork observation showed that, the indigenous farmers were the people who reported their cases to the police after the traditional authorities could not resolve the tension between them and the Fulani herders. The farmers knew that reporting to the police was very expensive and time consuming, but they were willing to lodge the complains with them because once the police was involved, the Fulani herders pay at least close to the extent of damage or full compensation. Because of this, the Fulani herders disliked the idea of farmers reporting to the Police. They would have preferred dialogue with the farmers to settle their differences. From the interviewer's observation, the police did not reconcile and restore the relationship between the farmer and the herder. The police only ensured that the victim is catered for while the perpetrator is punished. After the police case, these parties come back into the communities as enemies and not as friends. The continuous use of the police has negative implications on the promotion of peaceful coexistence even when there was only a minor conflict.

Secondly, although the traditional rulers have the power to manage common resources, settle disputes, enforce and impose sanctions on community members, the perception that the traditional council has been involved in the creation of the conflict in the Agogo Township by leasing lands to some groups of Fulani herders led the community to distrust their own traditional leaders. In addition, the traditional council was silent at the initial stages of the conflict, and both the farmers and the Fulani herders interpreted the "silence" negatively. Actually, these negative perceptions raised questions of 'legitimacy' of local practices (Wallis, 2016), which is linked to the power vested in the traditional council to be the custodian of all farmlands. As explained by Paffenholz (2015), there is always the question of 'in whose 
Migration, Farmer-Herder Conflict and the Challenges of Peacebuilding in the Agogo Traditional Area, Ghana

interest are the traditional and local elites serving?' Once the farmers and herders raise such questions, it becomes difficult to pursue durable peace. Both indigenous farmers and the migrant herders thought the silence reflected the Council's approval of violence initiated by each party. While the farmers mistrusted the traditional council for selling out community lands to 'strangers', the Fulani herders also blamed the traditional council for not defending them as legal occupants of the parcel of land which was leased to them. The Council could not play its conflict resolution and mediation role, as both sides did not trust it. Generally, the resilience of the local is significant because the local people challenged their own long-standing customs. Just as the inclusion of the local practices such as norms and values among others is important for peacebuilding, the breakdown of such local practices as in the case of the ATA is also critical (Wallis, 2016).

In order to self-defend themselves, the Fulani herders had developed their own means of resisting the threat of expulsion. They maintained that the 1997 land agreement gave them access to land. Through the interviews, the Fulani herders ${ }^{2}$ also argued that the cattle belonged to others and they were only following orders from the cattle owners, who lived in the cities and remunerated them on a monthly basis. The 'big men' visited once a month to supervise their investments. In the opinion of many Fulani herders, they were only caretakers, although some of them owned a few of the cattle. A sizeable number of livestock under Fulani care belonged to Ghanaian stockowners, including chiefs, who continued to employ Fulani to manage their animals (Yembilah \& Grant, 2014; Olaniyan et al., 2015; Soeters et al., 2017). This also gave the Fulani herders some form of political connections to both local and national politicians who also helped them to penetrate farming communities, ensure the security of their 
settlements and give them opportunities to access land resources (Yembilah \& Grant, 2014). Yembilah \&Grant (2014) argue that, the herders' networks with community leaders give them access to pastureland, which then hinders the promotion of peace among farmers and herders in ATA. Once again, the question is asked how legitimate are these local elite and traditional powers? In this context, it is empirically obvious that they served their own self-aspirations Paffenholz (2015).

Another challenge that hinder the management of the conflict in ATA was the language. Language was a challenge between the Fulani herders and the indigenous farmers. The history of Fulani shows that they learn the language of the host community, yet, in the case of Agogo traditional area, only a handful of Fulani herders said they could speak the language of the people of ATA. A focus group discussion with some female and male farmers indicated otherwise of the claims of the Fulani herders. The female farmers explained the problems they have with the herders due to the absence of a common language:

If the Fulani want to harm you, then they will tell you they cannot speak Twi. Some of them speak Twi and they speak Hausa; they speak both Twi and Hausa... If you meet the Fulani herder and he says he cannot speak Twi, he is telling a lie. Am I lying? [The whole group shouted, you are speaking the truth] They all speak Twi. It is when they see that they have caused some destruction, then at that moment they will tell us that they don't speak Twi; but they speak Twi, they understand it very well (ATA, November 4, 2017)

Even though from observation, some Fulani could not express themselves in the indigenous language, the farmers on the other hand disagreed and interpreted the herder's response as deliberate to harm farmers. Indeed, these consistent disagreements also pose challenges to the peace process in Agogo. 
Migration, Farmer-Herder Conflict and the Challenges of Peacebuilding in the Agogo Traditional Area, Ghana

\section{Conclusion}

The article has examined the role of the local peacebuilding actors, especially the AWA, which is a diaspora association, and the lived experiences of the herders and farmers in transforming the conflict between the two groups in Agogo traditional area. The article found that several bottom-up activities were organized with the aim of resolving the conflict. These activities included peace sensitization programs, mediation, negotiations, fund raising and dialogue, informal conversation, which have had positive impact in peacebuilding in ATA. However, these benefits were not without challenges, tensions were raised due to the arbitration by the court of law, the police as well as the break-down of traditional means of adjudicating cases through chiefs. In the case of the court, it is not seen as a peacebuilding element since it is an external arbiter that does not understand the context of the conflict, which may affect the ruling.

Although the Ghanaian diaspora is known to contribute to infrastructural development in the origin areas as well as the wellbeing of the families left behind (see Mangala, 2017; Setrana and Kyei, 2015), there is a gap when it comes to their involvement in peacebuilding. This article has argued that beyond the contribution of Ghanaian diaspora to infrastructural development, which is well documented in the diaspora and development discourse, they also play important role in promoting peacebuilding.

In the case of the farmer-herder conflict in Agogo Township, the AWA diaspora group are not external actors; they are local actors operating within the transnational space of living here and there. We conclude that AWA is positioned as middle level leaders according to Lederach's (1997) pyramid of peacebuilding because of the significant role they play. The article recommends that local peacebuilding be detached from adjudication in the court of law because the local actors perceive the court as external and ambivalent to the cultural context of local conflicts. 


\section{References}

Benjaminsen, T. A. and Ba, B. (2019). Why do pastoralists in Mali join jihadist groups? A political ecological explanation. The Journal of Peasant Studies, 46, 1, 120, DOI: $10.1080 / 03066150.2018 .1474457$.

Bukari, K.N., Sow, P., and Scheffran, J. (2018). Cooperation and Co-Existence between Farmers and Herders in the Midst of Violent Farmer-Herder Conflicts in Ghana. African Studies Review, 61, 2, 78-102. DOI: https://doi.org/10.1017/asr.2017.124

Bukari, K. N., and Schareika, N. (2015). Stereotypes, prejudices and exclusion of Fulani Pastoralists in Ghana. Pastoralism: Research, Policy and Practice, 5, 20, 1-12. https://doi.org/10.1186/s13570-015-0043-8.

Collier, P. (2000). Rebellion as a Quasi -Criminal activity. Journal of Conflict Resolution, 44, 6, 839-854. Retrieved July 23, 2021, from http://www.jstor.org/stable/174593.

Faist, T. (2005). The Migration-Security Nexus: International Migration and Security before and after 9/11. In Bodemann Y.M. and Yurdakul G (Eds), Migration, Citizenship, Ethnos: Incorporation Regimes in Germany, Western Europe and North America. London: Palgrave Macmillan.

Fetherston, A.B. (2000). Peacekeeping, conflict resolution and peacebuilding: A reconsideration of theoretical frameworks, International Peacekeeping, 7,1, 190218, DOI: $10.1080 / 13533310008413825$.

Galtung, J. (1975). Schooling and Future Society. The School Review, 83, 4, 533-568. Retrieved July 24, 2021, from http://www.jstor.org/stable/1084556.

Ghana Statistical Service (2013). 2010 Population and housing census: National analytic report. Accra: Ghana Statistical Service.

Kagwanja, P. (2003). Globalizing Ethnicity, Localizing Citizenship: Globalization, Identity Politics and Violence in Kenya's Tana River Region. African Development, 28, 1-2, 112-152.

Kaye, J. and Be' land, D. (2009). The politics of ethnicity and post-conflict reconstruction: the case of Northern Ghana. Journal of Contemporary African Studies, 27, 2, 177-200. DOI: $\underline{10.1080 / 02589000902867253 .}$

Kaye, Julie (2011). Informing Grassroots Development: The 1994-1995 Peacebuilding Experience in Northern Ghana. The Journal of Development Studies, 47, 3, 417-435, DOI: 10.1080/00220388.2010.506921.

Kuusaana, E.D. and Bukari, K.N. (2015). Land Conflicts between smallholders and Fulani Pastoralists in Ghana: Evidence from Asante Akim North District (AAND). Journal of Rural Studies, 42, 2, 52-62.

Lederach, J. (1997). Building Peace: Sustainable Reconciliation in Deeply Divided Societies. United States Institute for Peace: Washington, DC.

Lund, M.S. (2009). Conflict Prevention: Theory in Pursuit of Policy and Practice. In

Mac Ginty, R. (2014). Everyday peace: Bottom-Up and Local Agency in ConflictAffected Societies. Security Dialogue. 45, 6, 548-564.

Mahmood, S. (2005). Politics of Piety: The Islamic Revival and the feminist Subject. Princeton: Princeton University Press.

(2006). Secularism, Hermeneutics and Empire. The politics of Islamic Reformation. Public Culture. 18, 2, 323-347.

Mangala, J. (Eds) (2017). Africa and the Global Diaspora, African Histories and Modernities. New York: Springer.

Martin, P. (2012). Conflicts between pastoralists and farmers in Tana River District. In Witsenburg K and Zaal F (Eds.), Spaces of insecurity: Human agency in violent conflicts in Kenya (pp. 167-193). Leiden: African Studies Centre. 
Olaniyan, A., Michael, F. and Okeke-Uzodike, N. U. (2015) "The cattle are Ghanaians but the Herders are Strangers: Farmer-Herder Conflicts, Expulsion Policy, and Pastoralist in Agogo, Ghana." African Studies Quarterly 15, 2, 53-67.

Pablo, S. A. (2020). The Politics of addressing farmer-herder conflicts in Ghana. Peacebuilding http://doi.org/ 10.1080/21647259.2020.1740412.

Paffenholz, T. (2015). Unpacking the local turn in peace building: a critical assessment towards an agenda for future research. Third World Quarterly. 36, 5, 857-874.

DOI: $10.1080 / 01436597.2015 .1029908$.

Reimann, C. (2004). Assessing the state-of-the-art in conflict transformation: reflections from a theoretical perspective. In D. Bloomfield, M. Fischer, and B. Schmelzle (Eds), The Berghof Handbook for Conflict Transformation. Berghof Research Centre for Constructive Conflict Management: Berlin.

Setrana B. M. and Kyei, O. J. R. (2015). Transnational Paradigm Within Immigrant Political Integration Discourse, AFCO, Trans, 256, 91-101. https://doi.org/10.3917/afco.256.0091

Soeters, S., Weesie, R., and Zoomers, A. (2017). Agricultural investments and Farmer-Fulani pastoralist conflict in West African drylands: A northern Ghanaian case study. Sustainability, 9, 11, 20-63. https://doi.org/10.3390/su9112063.

Tonah, S. (2002). Fulani Pastoralists, indigenous farmers and the contest for land in Northern Ghana. Afrika Spectrum, 37,1, 43-59. Retrieved July 23, 2021, from http://www.jstor.org/stable/40174917.

Tonah, S. (2006). The Challenge of Fulani Pastoralism in Ghana. Legon Journal of International Affairs, 3, 1, 75-94.

Wallis, J. (2016). Is 'good enough' peacebuilding good enough? The potential and pitfalls of the local turn in peacebuilding in Timor-Leste. The Pacific Review, 30, 2, 251-269. https://doi.org/10.1080/09512748.2016.1220417.

Yakohene, A.B. (2018). Peacebuilding in Micro-level Inter-Community Conflicts in West Africa. In Omeje K (Eds), Peacebuilding in Contemporary Africa: In search of Alternative Strategies, London: Routledge.

Yembilah, R. and Grant, M. (2014). The political ecology of territoriality: Territorialities in farmer-herder relationships in northern Ghana. GeoJournal, 79, 3, 385- 400. https://doi.org/10.1007/s10708-013-9509-7. 